\title{
Imunoslobulina para Tratamento da Hemorragia Alveolar
}

\section{Immunoglobulin as a treatment for alveolar hemorrhage}

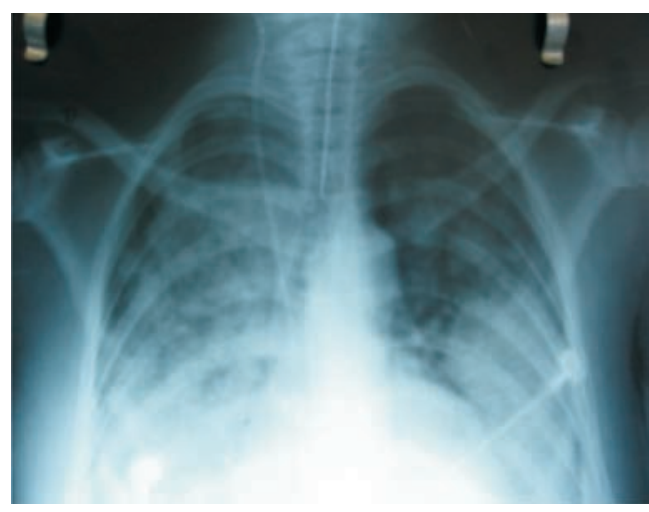

Figura 1

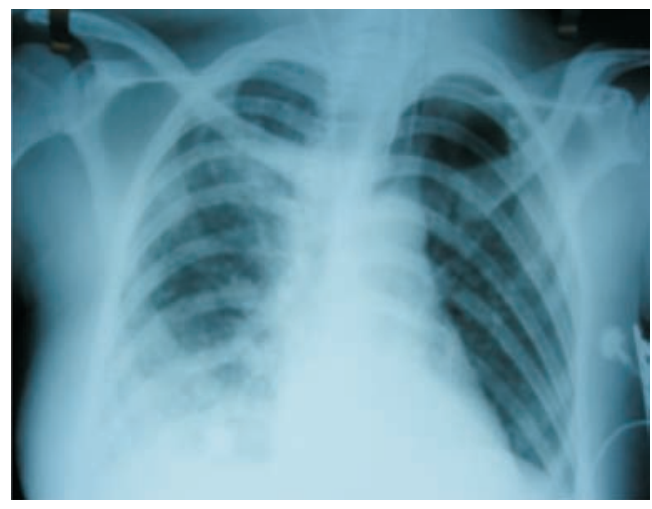

Figura 2

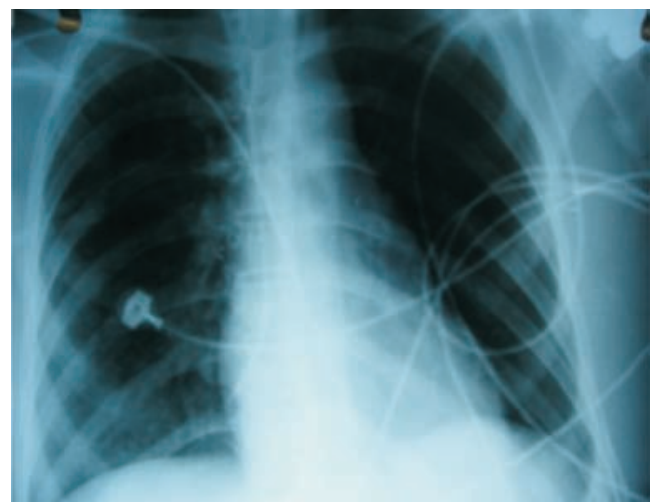

Figura 3

Paciente MIS, 25 anos, com diagnóstico de LES há um ano e em uso apenas de prednisona $20 \mathrm{mg} / \mathrm{dia}$. Apresentava artrite, alopecia e rash malar, além de FAN e anti-DNA positivos. Foi internada na Santa Casa em razão de nefrite, com hipertensão arterial e insuficiência renal, motivo pelo qual se optou pela pulsoterapia mista. No primeiro dia após a pulso, evoluiu com hemoptise volumosa e insuficiência respiratória, com necessidade de ventilação mecânica. $\mathrm{O}$ raio $\mathrm{X}$ realizado no primeiro dia de CTI (Figura 1) mostrou extensa consolidação, caracterizando um quadro de hemorragia alveolar. Foi, então, iniciada imunoglobulina EV na dose de $2 \mathrm{~g} / \mathrm{kg}$ em dois dias. Com o tratamento, houve rápida melhora radiológica, como pode ser visto nas radiografias de 24 horas (Figura 2) e 48 horas (Figura 3), após a infusão. Entretanto, após três semanas, houve recorrência da hemorragia, com rápida evolução para o óbito.

Portanto, mesmo com melhora radiológica inicial, o desfecho foi desfavorável, fato freqüentemente observado em pacientes lúpicos com esse tipo de complicação.

Caso encaminhado pelos residentes Janaína G. Netto, Lílian S. Santos e Renato V. Consoli; Eduardo J. R e Souza, chefe da Residência de Reumatologia da Santa Casa de Belo Horizonte e Paulo M. Pádua, chefe do Serviço de Reumatologia da Santa Casa de Belo Horizonte (MG). Lílian Santuza Santos. Rua Tenente Garro, 137/1001 CEP 30240-360, Belo Horizonte, $M G$, e-mail: lilian.santuza@terra.com.br 